\title{
A sulfydryl-based near-infrared ratiometic fluorescent probe for assessment of acute/chronic mercury exposure via associated determination of superoxide anion and mercury ion in cells and in vivo
}

\author{
Yue Wang ${ }^{\mathrm{a}, \mathrm{c}}$, Min Gao ${ }^{\mathrm{a}, \mathrm{c}}$, Chunyang Liao ${ }^{\mathrm{b}}$, Fabiao $\mathrm{Yu}^{\mathrm{a}, *}$, Lingxin Chen ${ }^{\mathrm{a}, *}$ \\ ${ }^{a}$ CAS Key Laboratory of Coastal Environmental Processes and Ecological Remediation, Research Centre for Coastal Environmental Engineering and Technology, Yantai \\ Institute of Coastal Zone Research, Chinese Academy of Sciences, Yantai, 264003, China \\ ${ }^{\mathrm{b}}$ State Key Laboratory of Environmental Chemistry and Ecotoxicology, Research Center for Eco-Environmental Sciences, Chinese Academy of Sciences, Beijing, 100085, \\ China \\ ${ }^{\mathrm{c}}$ University of Chinese Academy of Sciences, Beijing, 100049, China
}

\section{A R T I C L E I N F O}

\section{Keywords:}

Mercury poisoning

Near-infrared fluorescent probe

Ratiometric biomaging

Superoxide anion

Mercury ion

\begin{abstract}
A B S T R A C T
Mercury exposure is associated with severe oxidative stress especially superoxide anion radicals $\left(\mathrm{O}_{2}{ }^{-}\right)$. Mercury exposure is common in the clinic, but it is difficult to track. Although many researchers have tried to reveal the mechanism of mercury exposure, it is still remain vague that the differences between acute mercury exposure and chronic mercury exposure as well as the fluctuations in $\mathrm{O}_{2}{ }^{-}-$during mercury ion $\left(\mathrm{Hg}^{2+}\right)$ stress. Thus effective tool for $\mathrm{O}_{2}{ }^{-}$and $\mathrm{Hg}^{2+}$ associated-detection is needed urgently. Herein we have developed a stable near-infrared ratiometric fluorescent probe, $\mathrm{HCy}-\mathrm{SH}$, for $\mathrm{O}_{2}{ }^{-}-$and $\mathrm{Hg}^{2+}$ associated-detection. Probe $\mathrm{HCy}-\mathrm{SH}$ was designed and synthesized based on a heptamethine cyanine fluorophore and a thiol-responsive group. The probe HCy-SH can be used for mercury poisoning detection in HEK 293 cells and mice models with low detection limits of $65 \mathrm{nM}$ for $\mathrm{O}_{2}{ }^{\cdot-}$ and $72 \mathrm{nM}$ for $\mathrm{Hg}^{2+}$. Relying on the probe $\mathrm{HCy}-\mathrm{SH}$, we found that $\mathrm{O}_{2}{ }^{-{ }^{-}}$burst was much severer in acute mercury exposure than chronic mercury exposure, especially in heart, and $\mathrm{Hg}^{2+}$ mainly accumulated in kidney no matter acute mercury exposure or chronic mercury exposure. The experimental results indicated that the probe $\mathrm{HCy}-\mathrm{SH}$ was a potential candidate for accurate diagnosis and efficacy evaluation of mercury exposure.
\end{abstract}

\section{Introduction}

Mercury ion $\left(\mathrm{Hg}^{2+}\right)$ is one of the most toxic heavy metal ions due to severe bioaccumulation and protein targeting [1-3]. Once it enters into organisms, $\mathrm{Hg}^{2+}$ attacks the sulfhydryl (-SH) group of enzymes or proteins, and leads to a series of mercury-related diseases in the kidney, central nervous and endocrine system [4-7]. In addition to common chronic mercury exposures, acute mercury exposure also occurs frequently. Comparative studies of pathological changes in acute mercury exposure and chronic mercury exposure are significant for precise diagnosis of mercury poisoning. Though lots of drugs have been used for the treatment of mercury poisoning, the effects are unsatisfactory. For instance, sodium selenite can effectively antagonize $\mathrm{Hg}^{2+}$ but can't reduce the high level of $\mathrm{O}_{2}{ }^{-}-$immediately [8]. We have noticed that selenocysteine can also act as an efficient antagonist for $\mathrm{Hg}^{2+}$ and selenocysteine has been recognized as the first-line antioxidant against oxidative stress $[9,10]$. It is valuable to compare the antagonistic effect of sodium selenite and selenocysteine for mercury poisoning.

Superoxide anion $\left(\mathrm{O}_{2}{ }^{-}\right)$is a primary reactive oxygen species (ROS) which is mainly from the electron transport of the mitochondrial respiratory chain [11]. $\mathrm{O}_{2}{ }^{\cdot-}$ is a precursor of other ROS, and it can easily convert to other ROS through enzymatically or non-enzymatically ways [12]. Thus, $\mathrm{O}_{2}{ }^{-}$- can be regarded as the original source of other ROS [12] $\mathrm{O}_{2} \cdot{ }^{-}$burst can be caused by $\mathrm{Hg}^{2+}$ from two aspects [13]. On the one hand, $\mathrm{Hg}^{2+}$ as an intruder directly triggers $\mathrm{O}_{2}{ }^{--}$bursts [13]. On the other hand, $\mathrm{Hg}^{2+}$ can combine with sulfhydryl-containing antioxidants to impair the antioxidant capacity of organisms [13]. To completely elaborate the complicated relationship between $\mathrm{O}_{2}{ }^{--}$and $\mathrm{Hg}^{2+}$, efficient tools for $\mathrm{O}_{2}^{-{ }^{-}}$and $\mathrm{Hg}^{2+}$ detection are needed urgently.

The traditional methods for $\mathrm{Hg}^{2+}$ detection include gas chromatography, high performance liquid chromatography-mass spectrometry or atomic spectroscopy [14].The approaches for $\mathrm{O}_{2}{ }^{\cdot-}$ detection are generally based on electron paramagnetic resonance, HPLC, or mass spectrometry (MS) $[15,16]$. However, these methods usually destroy

\footnotetext{
* Corresponding authors.

E-mail addresses: fbyu@yic.ac.cn (F. Yu), 1xchen@yic.ac.cn (L. Chen).
} 
tissue samples and can't achieve real-time detection [17]. Fluorescence imaging technology has been widely applied for rapid detection of small molecules owing to its great advantages in biological sample imaging, such as superior selectivity, outstanding sensitivity, less invasion, high spatial and temporal resolution $[18,19,38]$. Now a series of fluorescent probes have been developed for $\mathrm{O}_{2}{ }^{-}-$and $\mathrm{Hg}^{2+}$ separately detection, and most of them just offer single signal output $[19,20,25,26]$. It's disappointing that the fluorescent probes with a single signal potentially suffer from the interferences from excitation and emission efficiency, as well as other labile environmental factors. Ratiometric fluorescent probes employ the ratio of two or more emission signals can avoid the above interferences and also greatly improve the quality of fluorescence imaging [21-23]. Moreover, the ratiometric fluorescent probes benefit from its self-calibration in light sources fluctuations and the fluorophore photobleaching [24].

Herein, we developed a stable three-channel ratiometric fluorescent probe, $\mathrm{HCy}-\mathrm{SH}$, for $\mathrm{O}_{2}{ }^{--}$and $\mathrm{Hg}^{2+}$ associated-detection. Sulfhydryl $(-\mathrm{SH})$ was chosen as the response site for $\mathrm{Hg}^{2+}$ detection due to its excellent selectivity and stability. $\mathrm{HCy}-\mathrm{SH}$ was applied for $\mathrm{O}_{2}{ }^{-{ }^{-}}$and $\mathrm{Hg}^{2+}$ detection in vitro and in vivo successfully. The results from cell imaging indicated that $\mathrm{Hg}^{2+}$ caused severe $\mathrm{O}_{2} \cdot$ - burst and cell damage. We evaluated the cell damage through detecting the mitochondrial membrane potential by JC-1, the apoptotic rate of cells using Annexin V/7-AAD Apoptosis Detection Kit and cell morphology with transmission electron microscope (TEM). The probe was further applied for $\mathrm{O}_{2}{ }^{-}-$ and $\mathrm{Hg}^{2+}$ detection in mice models of acute and chronic mercury exposure. Besides the tissue damages were detected by TUNEL staining, PI staining, and H\&E staining.

\section{Experimental section}

\subsection{Confocal imaging}

Taking $\mathrm{O}_{2}{ }^{-}-$detection as an example to describe the detection steps: the cells were incubated in culture plate $(\Phi=20 \mathrm{~mm})$ for $24 \mathrm{~h}$ to adhere before imaging. The cells were incubated with $1 \mu \mathrm{M} \mathrm{O}_{2}{ }^{-}$for $15 \mathrm{~min}$, and then $1 \mu \mathrm{M}$ HCy-SH was added for $10 \mathrm{~min}$. Next, the fluorescence signals were collected using a laser scanning confocal microscope (Japan Olympus Co., Ltd). The collection wavelengths were $755-840 \mathrm{~nm}$ (channel $1, \lambda_{\text {ex }}=635 \mathrm{~nm}$ ), 545-570 nm (channel $2, \lambda_{\text {ex }}$ $=488 \mathrm{~nm}$ ) and $570-670 \mathrm{~nm}$ (channel $3, \lambda_{\mathrm{ex}}=535 \mathrm{~nm}$ ). The excitation and emission wavelengths of the probe were channel $1: \lambda_{\text {ex/em }}=634$ / $777 \mathrm{~nm}\left(\right.$ Cy-S); channel 2: $\lambda_{\mathrm{ex} / \mathrm{em}}=486 / 562 \mathrm{~nm}(\mathrm{Cy}=\mathrm{S})$; channel 3: $\lambda_{\text {ex/em }}=510 / 607 \mathrm{~nm}$ (Keto-Cy). In the dye channel, the excitation wavelength was $488 \mathrm{~nm}$, and the collection wavelength was $500-530 \mathrm{~nm}$.

\subsection{Mice models of mercury exposure}

In the process of acute mercury exposure, the mice in group a-f were given with different gastric dose (group a: $0.2 \mathrm{ml}$ saline; group b: $4 \mathrm{mg} / \mathrm{Kg}$, group c: $8 \mathrm{mg} / \mathrm{Kg}$, group d: $12 \mathrm{mg} / \mathrm{Kg}$, group e: $16 \mathrm{mg} / \mathrm{Kg}$, group f: $20 \mathrm{mg} / \mathrm{Kg} \mathrm{HgCl}_{2}$ ) for $16 \mathrm{~h}$. In the treatment group g, the mice were given $\mathrm{HgCl}_{2}(20 \mathrm{mg} / \mathrm{Kg})$ and sodium selenite $(0.5 \mathrm{mg} / \mathrm{Kg}$, $2.89 \mu \mathrm{M} / \mathrm{kg}$ ) orally by gavage for $16 \mathrm{~h}$. The mice in group $\mathrm{h}$ were given $\mathrm{HgCl}_{2}(20 \mathrm{mg} / \mathrm{Kg})$ and selenocysteine $(0.485 \mathrm{mg} / \mathrm{kg}, 2.89 \mu \mathrm{M} / \mathrm{kg})$ orally by gavage for $16 \mathrm{~h}$. In the process of chronic mercury exposure, the mice were given equal concentrations of $\mathrm{HgCl}_{2}(18 \mathrm{mg} / \mathrm{Kg})$ for different days: 10 days (group b); 15 days (group c); 20 days (group d); 25 days (group e); 30 days (group f). In the treatment group g, the mice were given $\mathrm{HgCl}_{2}(20 \mathrm{mg} / \mathrm{Kg})$ and sodium selenite $(0.5 \mathrm{mg} / \mathrm{Kg}, 2.89 \mu \mathrm{M} / \mathrm{kg})$ orally by gavage for 30 days. The mice in group h were given $\mathrm{HgCl}_{2}$ $(20 \mathrm{mg} / \mathrm{Kg})$ and selenocysteine $(0.485 \mathrm{mg} / \mathrm{kg}, 2.89 \mu \mathrm{M} / \mathrm{kg})$ orally by gavage for 30 days.

Physiological observation: mice in the control group behaved normally. The mice in the group of mercury exposure (including treatment groups) exhibited abnormal behavioral symptoms: mice have dull eyes, slow and weak movement, wet and sparseness fur. The anatomy of the mice was observed as enlarged kidneys and darkened spleens. The color of the spleen of individual mice was purple-red.

Other detailed experimental steps and Ethics Statement are shown in the supporting information.

\section{Results and discussion}

\subsection{Design strategy and the detection mechanism of HCy-SH}

In our previous work, we have used a three-channel fluorescent probe for $\mathrm{O}_{2}{ }^{--}$and $\mathrm{Hg}^{2+}$ associated-detection and this work has aroused great attention [8]. We hope to further reveal the differences between acute and chronic mercury poisoning for better diagnosis and treatment of mercury poisoning. In addition, there are strong demands to investigate the efficacy of selenocysteine for the treatment of mercury poisoning. However, the stability of our previous probe $\mathrm{HCy}-\mathrm{SeH}$ can't meet the long-term testing requirements. Hence we strive to conceive a more stable fluorescent probe for mercury poisoning detection. As known, the $\mathrm{Ksp}$ of $\mathrm{HgS}$ is $3 \times 10^{-52}$ and the $-\mathrm{SH}$ group is stable [31]. The -SH tends to complex with $\mathrm{Hg}^{2+}$ and acts as a response site towards $\mathrm{Hg}^{2+}$ [32-36]. Given the great advantages of threechannel ratiometric fluorescent probe, we continue to use heptamethine cyanine dye as fluorophore [8]. Besides, the fluorophore has great merit that the meso-position of the fluorophore facilitates the substitution of -SH to conceive a new probe [37]. The reaction mechanism of probe is shown in Scheme 1.

\subsection{Spectroscopic properties of the probe towards $\mathrm{O}_{2}{ }^{-{ }^{-}}$and $\mathrm{Hg}^{2+}$}

The spectroscopic properties of probe HCy-SH were detected under the simulated physiological conditions (10 mM HEPES, $\mathrm{pH} 7.4)$. As shown in Fig. 1a, an absorption peak centered at $486 \mathrm{~nm}$ and a broad

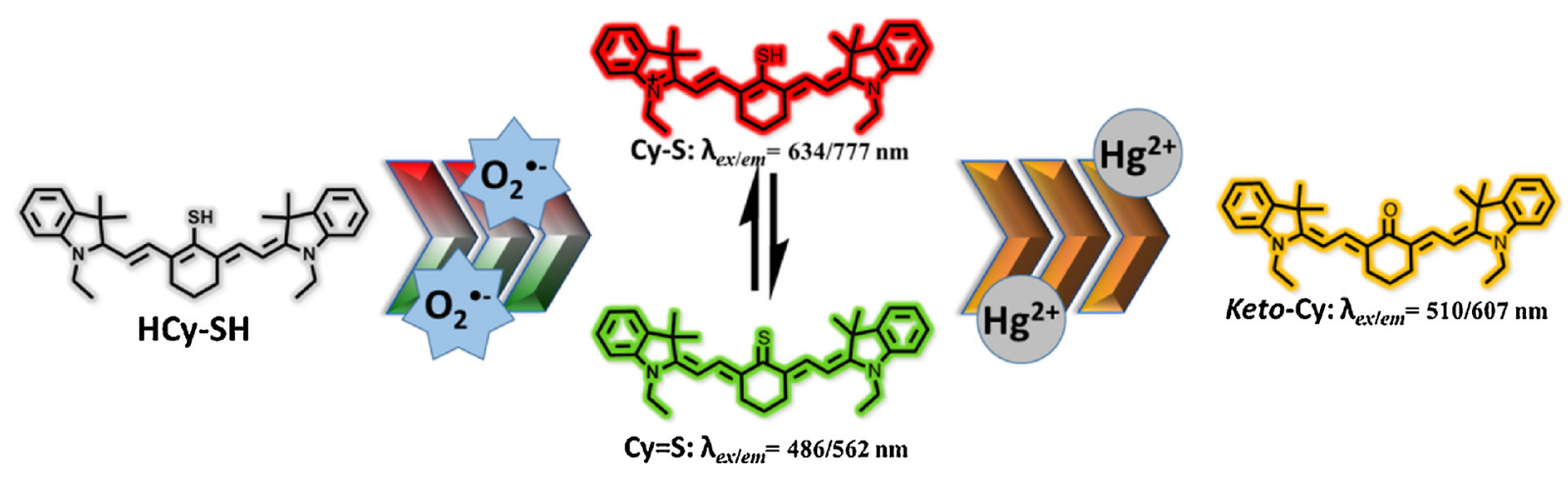

Scheme 1. Proposed associated-detection mechanism of $\mathrm{HCy}-\mathrm{SH}$ for $\mathrm{O}_{2}{ }^{-{ }^{-}}$and $\mathrm{Hg}^{2+}$. 

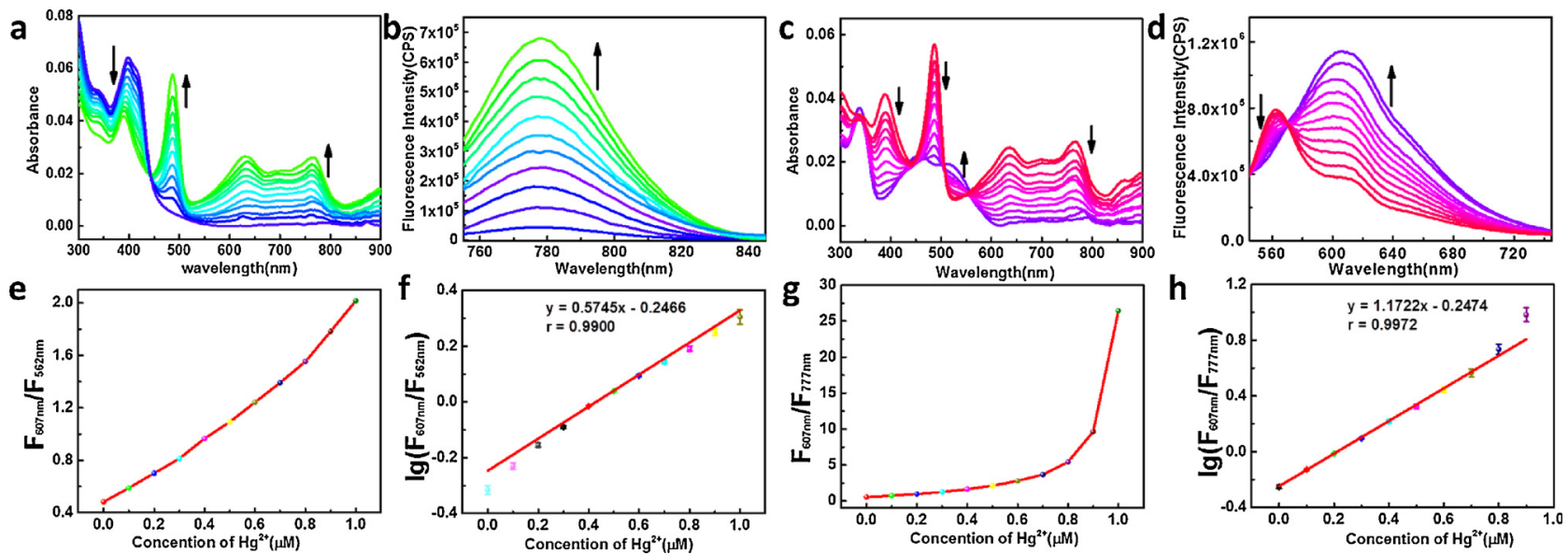

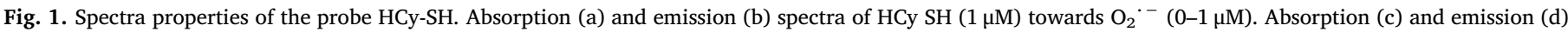

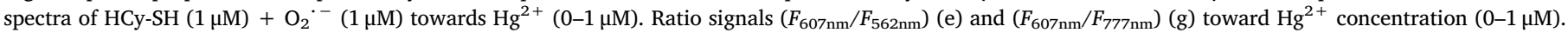
The corresponding linear relationships between the $\lg \left(F_{607 \mathrm{~nm}} / F_{562 \mathrm{~nm}}\right)(\mathrm{f}) / \lg \left(F_{607 \mathrm{~nm}} / F_{777 \mathrm{~nm}}\right)(\mathrm{h})$ and the $\mathrm{Hg}{ }^{2+}$ concentration $(0-1 \mu \mathrm{M})$.

absorption band ranged from $630 \mathrm{~nm}$ to $767 \mathrm{~nm}$ increased gradually with the addition of $\mathrm{O}_{2}{ }^{--}(0-1 \mu \mathrm{M})$, indicating the $\pi$-electron system of HCy-SH recovered. Before $\mathrm{Hg}^{2+}$ detection, probe $\mathrm{HCy}-\mathrm{SH}(1 \mu \mathrm{M})$ was pretreated with $1 \mu \mathrm{M} \mathrm{O}_{2}{ }^{-}$, and then different concentrations of $\mathrm{Hg}^{2+}$ $(0-1 \mu \mathrm{M})$ were added into the mixture. We found that the absorption peak at $486 \mathrm{~nm}$ and the broad absorption band both decreased, while a new absorption peak at $510 \mathrm{~nm}$ appeared and increased gradually with the $\mathrm{Hg}^{2+}$ concentration increased (Fig. 1c). Owing to the hydrocyanine interrupted the $\pi$-electron system of polymethine, the free probe $\mathrm{HCy}$ SH showed no emission profiles. After reacted with $\mathrm{O}_{2}{ }^{-}$, the probe recovered its $\pi$-electron system and emitted strong fluorescence with the emission peak centered at $777 \mathrm{~nm}$, and its alkaline form $\mathrm{Cy}=\mathrm{S}$ centered at $562 \mathrm{~nm}$ (Fig. 1b and d). The results showed good linear relationships between the fluorescence intensities and the $\mathrm{O}_{2}{ }^{--}$concentrations $(0-1 \mu \mathrm{M})$ (Fig. S1). The detection limits were determined to be $65 \mathrm{nM}(777 \mathrm{~nm})$ and $80 \mathrm{nM}(562 \mathrm{~nm})(3 \sigma / k)$.

The spectra properties for $\mathrm{Hg}^{2+}$ detection were plotted in Fig. 1d. With the increase of $\mathrm{Hg}^{2+}$ concentration $(0-1 \mu \mathrm{M})$, the intensity of emission peak at $607 \mathrm{~nm}$ increased gradually, while the emission peaks at $562 \mathrm{~nm}$ and $777 \mathrm{~nm}$ decreased. There were also good linear relationships between logarithm of the ratios $\left(F_{607 \mathrm{~nm}} / F_{562 \mathrm{~nm}}, F_{607 \mathrm{~nm}} /\right.$ $F_{777 n m}$ ) and the $\mathrm{Hg}^{2+}$ concentrations (Fig. If and h). The regression equations were $\lg \left(F_{607} \mathrm{~nm} / F_{562 \mathrm{~nm}}\right)=0.5745\left[\mathrm{Hg}^{2+}\right] \mu \mathrm{M}-0.2466$ with $\mathrm{r}=0.9900$ and $\lg \left(F_{607 \mathrm{~nm}} / F_{777 \mathrm{~nm}}\right)=1.1722\left[\mathrm{Hg}^{2+}\right] \mu \mathrm{M}-0.2474$ with $\mathrm{r}=0.9972$. The detection limits were $72 \mathrm{nM}\left(F_{607 \mathrm{~nm}} / F_{562 \mathrm{~nm}}\right)$ and $94 \mathrm{nM}\left(F_{607 \mathrm{~nm}} / F_{777 \mathrm{~nm}}\right)$ respectively. The results confirmed that probe $\mathrm{HCy}-\mathrm{SH}$ possessed the ability for qualitative and quantitative detection of $\mathrm{O}_{2}{ }^{-}-$and $\mathrm{Hg}^{2+}$.

As an efficient probe, high selectivity is the prerequisite for widespread applications. So the selectivity tests of $\mathrm{HCy}-\mathrm{SH}$ for $\mathrm{O}_{2}{ }^{-}$and $\mathrm{Hg}^{2+}$ were performed. The interference from physiological relevant ROS, reactive nitrogen species (RNS) and many metal ions were used to evaluate the selectivity of HCy-SH. As shown in Fig. S2(a), the fluorescence signals from methyl linoleate hydroperoxide, $\mathrm{H}_{2} \mathrm{O}_{2}$, tert-butyl hydroperoxide, cumene hydroperoxide, $\mathrm{OH}, \mathrm{GSH}$, Cys, Hcys, GSSG, Cys-SS-Cys, Cys-SSH, GSSH, NO and ONOO- were negligible. However, the fluorescence intensity of the probe after reacted with $\mathrm{O}_{2}{ }^{-}$- was obvious. The experimental results proved that the probe exhibited high selectivity towards $\mathrm{O}_{2}{ }^{-}-$. Then the fluorescence response of the probe towards various metal ions was also examined. As shown in Fig. S2(b), only $\mathrm{Hg}^{2+}$ caused strong fluorescence signals. Other metal ions, like $\mathrm{Co}^{2+}, \mathrm{K}^{+}, \mathrm{Ca}^{2+}, \mathrm{Fe}^{3+}, \mathrm{Zn}^{2+}, \mathrm{Mg}^{2+}, \mathrm{Na}^{+}, \mathrm{Mn}^{2+}, \mathrm{Cd}^{2+}, \mathrm{Cu}^{2+}, \mathrm{Pb}^{2+}$ and $\mathrm{Ni}^{2+}$ caused ignorable fluorescence signals. These results demonstrated that the probe had a good selectivity towards $\mathrm{Hg}^{2+}$. The above results confirmed that our probe could work well under the simulated physiological conditions. To further explore the influence of excess $\mathrm{O}_{2}{ }^{\circ}-$ on $\mathrm{Hg}^{2+}$ detection, $20 \mu \mathrm{M} \mathrm{O}_{2}{ }^{\circ}$ - was firstly added into the solution, and then the $\mathrm{Hg}^{2+}$ was added. As shown in Fig. S2b column 15, excess $\mathrm{O}_{2}{ }^{\circ}$ didn't affect $\mathrm{Hg}^{2+}$ detection. Moreover, the reaction kinetics of $\mathrm{HCy}-\mathrm{SH}$ was examined and the results indicated $\mathrm{HCy}-\mathrm{SH}$ was a good candidate for rapidly detection of $\mathrm{O}_{2}{ }^{--}$and $\mathrm{Hg}^{2+}$ (Fig. S3).

\section{3. $\mathrm{O}_{2}{ }^{--}$and $\mathrm{Hg}^{2+}$ imaging in cell models}

HEK 293 cell line was chosen for $\mathrm{O}_{2}{ }^{--}$and $\mathrm{Hg}^{2+}$ detection. Before cell imaging, MTT experiments were conducted to detect the cytotoxicity of HCy-SH. The high cell viability of HEK 293 cells demonstrated the low cytotoxicity of the probe (Fig. S6). Cells in Fig. 2 were treated as follows: group a) $1 \mu \mathrm{M} \mathrm{HCy}-\mathrm{SH}$ for $10 \mathrm{~min}$ (as control); group b) $1 \mu \mathrm{M}$ $\mathrm{O}_{2} \cdot$ - for $15 \mathrm{~min}$; group c) $1 \mu \mathrm{M} \mathrm{O}_{2}{ }^{\circ}$ - and $1 \mu \mathrm{M} \mathrm{Hg}^{2+}$ for 15 min; group d) phorbol myristate acetate (PMA, $10 \mathrm{nM}$ ) for $20 \mathrm{~min}$ to induce endogenous $\mathrm{O}_{2}{ }^{\circ}$-; group e) $10 \mathrm{nM}$ PMA and $1 \mu \mathrm{M} \mathrm{Hg}^{2+}$ for $20 \mathrm{~min}$; group f) $1 \mu \mathrm{M} \mathrm{Hg}^{2+}$ for $30 \mathrm{~min}$; group g) $6 \mu \mathrm{M} \mathrm{Hg}^{2+}$ for $30 \mathrm{~min}$; group h) pretreated with $3 \mu \mathrm{M}$ sodium selenite for $1 \mathrm{~h}, 1 \mu \mathrm{M} \mathrm{\textrm {Hg } ^ { 2 + }}$ for $30 \mathrm{~min}$; group i) pretreated with the $3 \mu \mathrm{M}$ selenocysteine for $1 \mathrm{~h}, 1 \mu \mathrm{M} \mathrm{Hg}^{2+}$ for $30 \mathrm{~min}$. As expected, we can't capture fluorescence signal in group a. In group $\mathbf{b}$, we observed strong fluorescence signals in channel 1, 2 as well as $\mathrm{O}_{2}{ }^{\circ}$ - channel. The results proved that the probe can be used for exogenous $\mathrm{O}_{2} \cdot$ - imaging. In group c, strong fluorescence signals were collected in the three channels and the $\mathrm{O}_{2}{ }^{-}$- channel. In group $\mathbf{d}$, we obtained bright fluorescence signals in channel 1,2 as well as $\mathrm{O}_{2}{ }^{-}$channel. Therefore the probe can effectively detect the endogenous $\mathrm{O}_{2}{ }^{-}$burst. In group $\mathbf{e}$ and $\mathbf{f}$, strong fluorescence signals were collected in all channels. These experiments results demonstrated that $\mathrm{Hg}^{2+}$ can induce ROS burst, and the probe $\mathrm{HCy}-\mathrm{SH}$ can be used for $\mathrm{O}_{2}{ }^{-}$and $\mathrm{Hg}^{2+}$ imaging. Then excessive $\mathrm{Hg}^{2+}$ was employed for experiment in group $\mathbf{g}$, and only channel 3 and $\mathrm{O}_{2} \cdot$ - channel showed bright signals. So we speculated that $\mathrm{O}_{2}{ }^{\circ}$ - oxidized $\mathrm{HCy}-\mathrm{SH}$ to $\mathrm{Cy}-\mathrm{SH}$, and then excessive $\mathrm{Hg}^{2+}$ converted all the Cy-SH to Keto-Cy so quickly that we can't obtain fluorescence in channel 1 and channel 2. Both sodium selenite and selenocysteine can be used for antagonizing $\mathrm{Hg}^{2+}$, thus sodium selenite and selenocysteine were selected for remedy of mercury poisoning $[27,28]$. In the group $\mathbf{h}$ and group $\mathbf{i}$, we captured strong signals only in channel 1 , channel 2 and $\mathrm{O}_{2}{ }^{\circ}$ - channel, and the results indicated that $\mathrm{Hg}^{2+}$ can be antagonized efficiently by selenium selenite and selenocysteine. The results of the fluorescence images were further confirmed by flow cytometry analysis. As shown in Fig. S7a, the results were consistent well with the fluorescence imaging in Fig. 2. Furthermore, the cell apoptosis and the mitochondrial membrane potential were detected for cell damage analyzing using Annexin V/7-AAD Apoptosis 


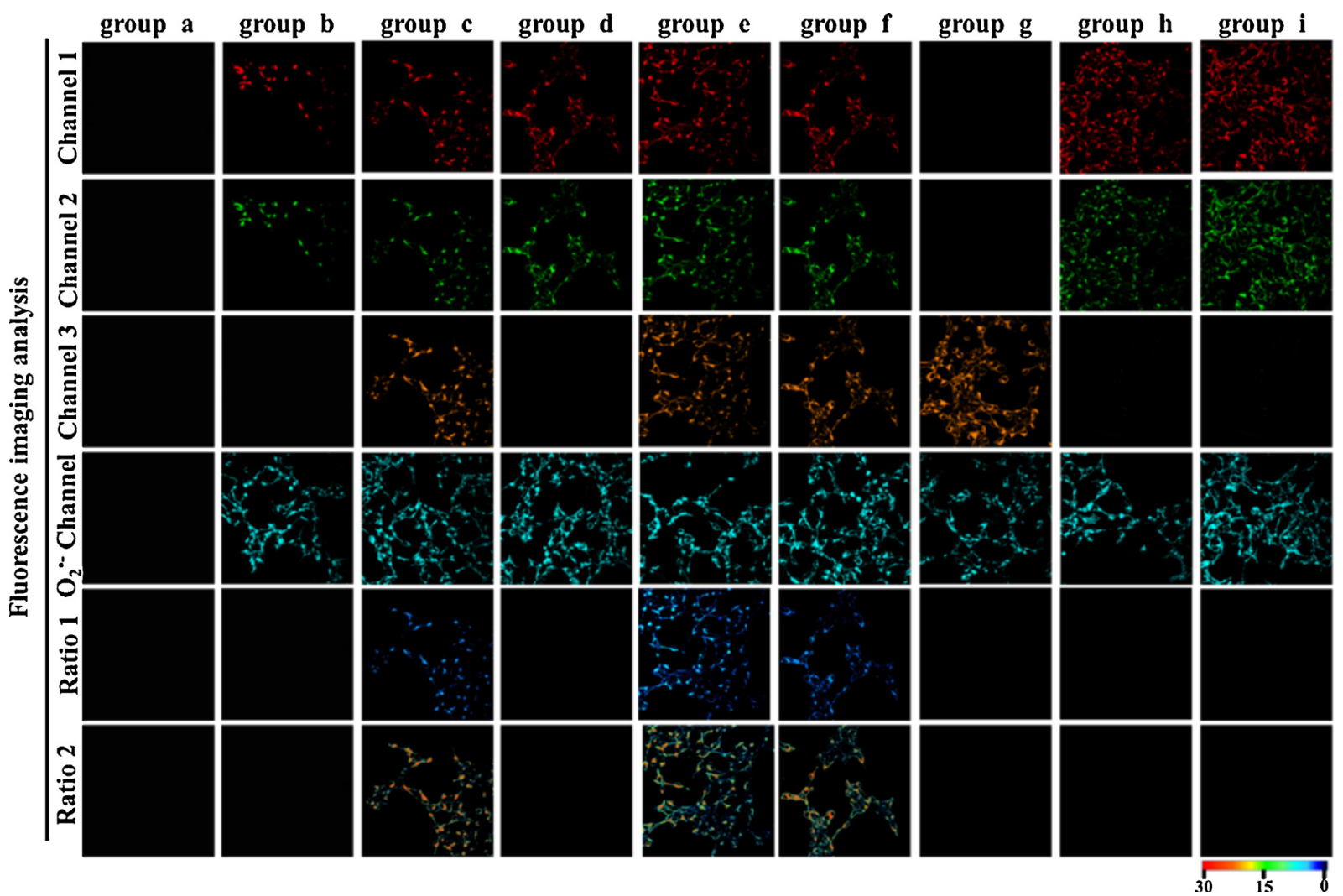

Fig. 2. $\mathrm{O}_{2}{ }^{-}$and $\mathrm{Hg}^{2+}$ detection in HEK 293 cells using laser scanning confocal microscope. Channel $1 \lambda_{\text {em }}=755-840 \mathrm{~nm}\left(\lambda_{\text {ex }}=635 \mathrm{~nm}\right)$; channel 2 $\lambda_{\mathrm{em}}=545-570 \mathrm{~nm}\left(\lambda_{\mathrm{ex}}=488 \mathrm{~nm}\right)$; channel $3 \lambda_{\mathrm{em}}=570-670 \mathrm{~nm}\left(\lambda_{\mathrm{ex}}=535 \mathrm{~nm}\right)$. Ratio 1: channel $3 v s$ channel 2; Ratio 2: channel $3 v s$ channel 1. The commercial dye channel $\left(\mathrm{O}_{2}{ }^{-}\right.$- channel) from 500 to $530 \mathrm{~nm}\left(\lambda_{\text {ex }}=488 \mathrm{~nm}\right)$. group a: $1 \mu \mathrm{M} \mathrm{HCy-SH;} \mathrm{group} \mathrm{b:} 1 \mu \mathrm{M} \mathrm{HCy-SH,} 1 \mu \mathrm{M} \mathrm{O}{ }^{\circ}-;$ group c: $1 \mu \mathrm{M} \mathrm{HCy}-\mathrm{SH}, 1 \mu \mathrm{M} \mathrm{O}_{2}{ }^{\circ}, 1 \mu \mathrm{M}$ $\mathrm{Hg}^{2+}$; group d: $1 \mu \mathrm{M} \mathrm{HCy-SH,} 10 \mathrm{nM}$ PMA; group e: $1 \mu \mathrm{M} \mathrm{HCy-SH,} 10 \mathrm{nM} \mathrm{PMA}, 1 \mu \mathrm{M} \mathrm{Hg}^{2+}$; group f: $1 \mu \mathrm{M} \mathrm{HCy-SH,} 1 \mu \mathrm{M} \mathrm{Hg}^{2+}$; group g: $1 \mu \mathrm{M} \mathrm{HCy-SH,} 6 \mu \mathrm{M} \mathrm{Hg}{ }^{2+}$; group h: $1 \mu \mathrm{M} \mathrm{HCy}-\mathrm{SH}, 3 \mu \mathrm{M}$ sodium selenite, $1 \mu \mathrm{M} \mathrm{Hg}^{2+}$; group i: $1 \mu \mathrm{M} \mathrm{HCy}-\mathrm{SH}, 3 \mu \mathrm{M}$ selenocysteine, $1 \mu \mathrm{M} \mathrm{Hg}^{2+}$.

Detection Kit and J-aggregate-forming lipophilic cation5,5',6,6'-tetrachloro-1,1',3,3'-tetraethylbenzim-idazolylcarbo-cyanine iodide (JC-1) (Fig. S7b and S7c). We also evaluated the cell damages with TEM. The results showed that mercury exposure can induce severe cell apoptosis. Although sodium selenite and selenocysteine can be used for mercury antagonism, the damage from $\mathrm{O}_{2}{ }^{-}$burst can't be repaired in a short period of time.

\subsection{Associated-detection of $\mathrm{O}_{2}{ }^{\cdot-}$ and $\mathrm{Hg}^{2+}$ in mice models of acute mercury exposure}

Encouraged by the successful application of the probe in cell models, we further applied HCy-SH for comparative studies of acute and chronic mercury exposure in mice models. The probe whose absorption and emission profiles locate at NIR owns advantages for fluorescence imaging because the NIR fluorescence can maximize tissue penetration depth, minimize the background auto-fluorescence and protect samples from photo damages. The preliminary results in Fig. S9 indicated that the probe can be successfully applied for the $\mathrm{O}_{2}{ }^{-}$and $\mathrm{Hg}^{2+}$ detection in vivo. Then we used HCy-SH as an effective molecular tool for $\mathrm{O}_{2} \cdot$ - and $\mathrm{Hg}^{2+}$ imaging in mice models of acute mercury exposure firstly. Fig. $3 \mathrm{a}$ and S16 showed the fluorescence imaging for $\mathrm{Hg}^{2+}$ and $\mathrm{O}_{2} \cdot$ - detection, respectively. In the current experiments, we tried to compare the concentration fluctuations of $\mathrm{O}_{2}{ }^{-}-$and $\mathrm{Hg}^{2+}$, detoxification effects of selenocysteine and sodium selenite, as well as tissue damages in acute mercury exposure and chronic mercury exposure. The mice models of acute mercury exposure were constructed with $\mathrm{HgCl}_{2}$. The mice in the control group were given $0.2 \mathrm{ml}$ saline (group a), and the mice in other groups were given equal volume $\mathrm{HgCl}_{2}$ solution with different dose (group b: $4 \mathrm{mg} / \mathrm{Kg}$, group c: $8 \mathrm{mg} / \mathrm{Kg}$, group d: $12 \mathrm{mg} / \mathrm{Kg}$, group e: $16 \mathrm{mg} / \mathrm{Kg}$, group f: $20 \mathrm{mg} / \mathrm{Kg}$ ) for $16 \mathrm{~h}$. We employed sodium selenite $(0.5 \mathrm{mg} / \mathrm{kg}, 2.89 \mu \mathrm{M} / \mathrm{kg})$ as an antidote for the treatment of mercury exposure in group $\mathrm{g}$. Selenocysteine is a kind of selenium-containing amino acids in vivo, which is regarded as mercury antagonist as well as the antioxidants in intracellular antioxidant defense system [13]. Next, we used selenocysteine $(0.485 \mathrm{mg}$ / $\mathrm{kg}, 2.89 \mu \mathrm{M} / \mathrm{kg}$ ) as another antidote for the treatment of mercury exposure in group $\mathbf{h}$. After constructed the mice models, the fresh tissue sections were obtained for quick fluorescence imaging analysis using probe HCy-SH. As shown in group a, the negligible fluorescence in channel 1 and channel 2 indicated the low concentration of $\mathrm{O}_{2}{ }^{-}$- in the control group (Fig. S16). However, the fluorescence intensities fluctuated in channel 1 and channel 2 with the simulation of different $\mathrm{Hg}^{2+}$ concentrations (group $\mathbf{b}-\mathbf{h}$ ). The results in Fig. S16 indicated that the degrees of $\mathrm{O}_{2} \cdot$ - burst were different among different organs, and the heart held the most severe $\mathrm{O}_{2}{ }^{\circ}-$ burst, which indicated that acute mercury exposure lead to seriously oxidative stress in heart. By increasing the gavage dose of $\mathrm{Hg}^{2+}$, the fluorescence in the kidney was increased obviously and much brighter than that in the other organs (Fig. 3a). This phenomenon proved that $\mathrm{Hg}^{2+}$ accumulated mainly in kidney. The concentrations of $\mathrm{O}_{2}{ }^{\circ}$ - were confirmed via a ROS probe, 2,7-dichlorodihydrofluorescein diacetate, through tissue homogenate (Fig. 3b). The concentrations of $\mathrm{Hg}^{2+}$ in different organs were confirmed by ICP-MS and the results were shown in Fig. 3c. These results in Fig. $3 \mathrm{~b}$ and $\mathrm{c}$ were consisted well with the results that from fluorescence imaging, which indicated that the probe was a powerful tool for $\mathrm{O}_{2}{ }^{-}$and $\mathrm{Hg}^{2+}$ detection.

Since $\mathrm{Hg}^{2+}$ tended to accumulate in kidney, the orthotopic injection assays of kidney were performed. The probe HCy-SH $(10 \mu \mathrm{M}, 10 \mu \mathrm{L}$, in 1:99 DMSO/saline v/v) was used for $\mathrm{O}_{2}{ }^{-}$and $\mathrm{Hg}^{2+}$ associated- 


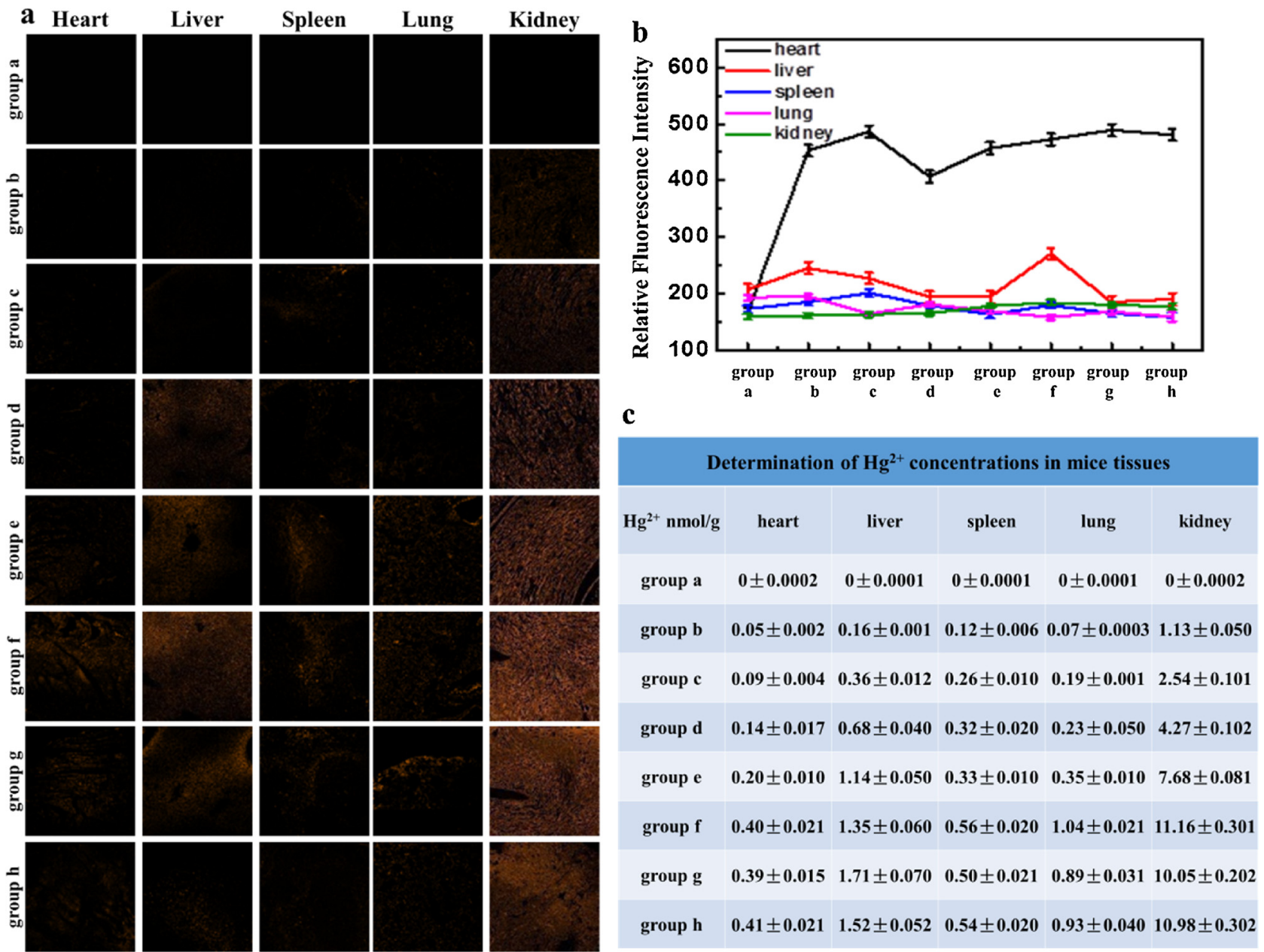

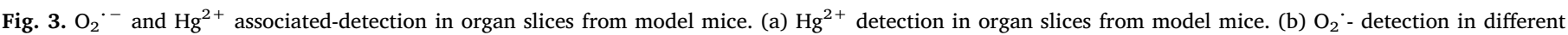

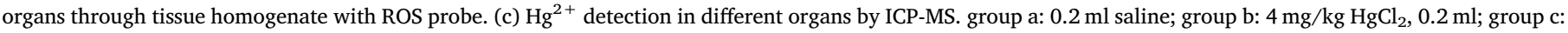

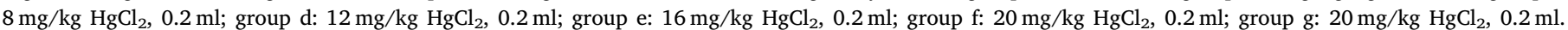
$2.89 \mu \mathrm{M} / \mathrm{kg}$ sodium selenite, $0.2 \mathrm{ml}$; group h: $20 \mathrm{mg} / \mathrm{kg} \mathrm{HgCl}_{2}, 0.2 \mathrm{ml} .2 .89 \mu \mathrm{M} / \mathrm{kg}$ selenocysteine, $0.2 \mathrm{ml}$.

detection in kidney (Fig. 4a). The probe was injected into kidneys through renal artery. After injection, the renal artery and renal vein were ligated soon. Then the fluorescence signals were collected with an in vivo imaging system through three-channel imaging. As illustrated in Fig. 4a, the fluorescence intensities from the mice model increased gradually with the concentrations of $\mathrm{Hg}^{2+}$ increased in the gavage experiment. Compared to the mice in group $\mathbf{f}$, the fluorescence intensity from the mice in the treatment group (group $\mathbf{g}$ and group $\mathbf{h}$ ) decreased. The results indicated that selenocysteine and sodium selenite can antagonize $\mathrm{Hg}^{2+}$ effectively. The relative fluorescence quantitative analysis was shown in Fig. 4g.

The kidneys of the mice in Fig. 4a were isolated rapidly for in vitro experiment (Fig. 4d). The fluorescence intensity increased gradually with the dose of $\mathrm{Hg}^{2+}$ increased, and the fluorescence intensity in the treatment groups decreased slightly. The relative fluorescence quantitative analysis was shown in Fig. 4h. TUNEL staining was employed to directly evaluate the apoptosis of cells through the cleavage of DNA. As shown in Fig. S19, with the concentration of $\mathrm{Hg}^{2+}$ increased, the degrees of tissue damage increased as well, and the degree of tissue damage alleviated in the treatment groups (group $\mathbf{g}$ and $\mathbf{h}$ ). The results were further confirmed by PI staining and the results were shown in Fig. S19. The hematoxylin and eosin (H\&E) staining in Fig. 4c was used for pathology observation. Clear glomeruli and regular nuclei can be observed in the control group. However, the glomeruli and nucleus deformed gradually with the $\mathrm{Hg}^{2+}$ concentrations increased, which indicated the tissue damage increased in kidney. The tissue damage can be relieved in the treatment groups by selenocysteine and sodium selenite. Next, we evaluated the changes of heat-shock protein 72 (hsp 72) under acute mercury exposure, because this protein would combine with other important proteins to prevent irreversible aggregation and denaturation as well as promote the proteins repair [29]. Due to the $\mathrm{Hg}^{2+}$ damage mainly in the cortex of the kidney, we extracted the protein from the cortex of the kidney. The expression levels of the protein hsp 72 were analyzed by western blot. As shown in Fig. 4e, the expression of hsp 72 was upregulated once simulated by $\mathrm{Hg}^{2+}$. However, in the treatment groups, the protein expression was downregulated. The expression levels of the protein were analyzed by the software Image $\mathrm{J}$ and the results were shown in Fig. 4f. The experiment results from acute mercury exposure model revealed that the outbreak of $\mathrm{O}_{2}{ }^{-}$- was much severer in heart. Sodium selenite and selenocysteine can protect the organisms from mercury poisoning, but the organisms damages can't be repaired in a short period of time.

\subsection{Associated-detection of $\mathrm{O}_{2}{ }^{\cdot-}$ and $\mathrm{Hg}^{2+}$ in mice models of chronic mercury exposure}

In the study of acute mercury exposure, the concentration of $\mathrm{O}_{2}{ }^{-}$ in the heart was the highest and the concentration of $\mathrm{Hg}^{2+}$ in the kidney was the highest. In this part, we explored the concentration changes of $\mathrm{O}_{2}{ }^{-}$- and $\mathrm{Hg}^{2+}$ in chronic mercury exposures. To realize our 
a Channel 1 Channel 2 Channel 3 b
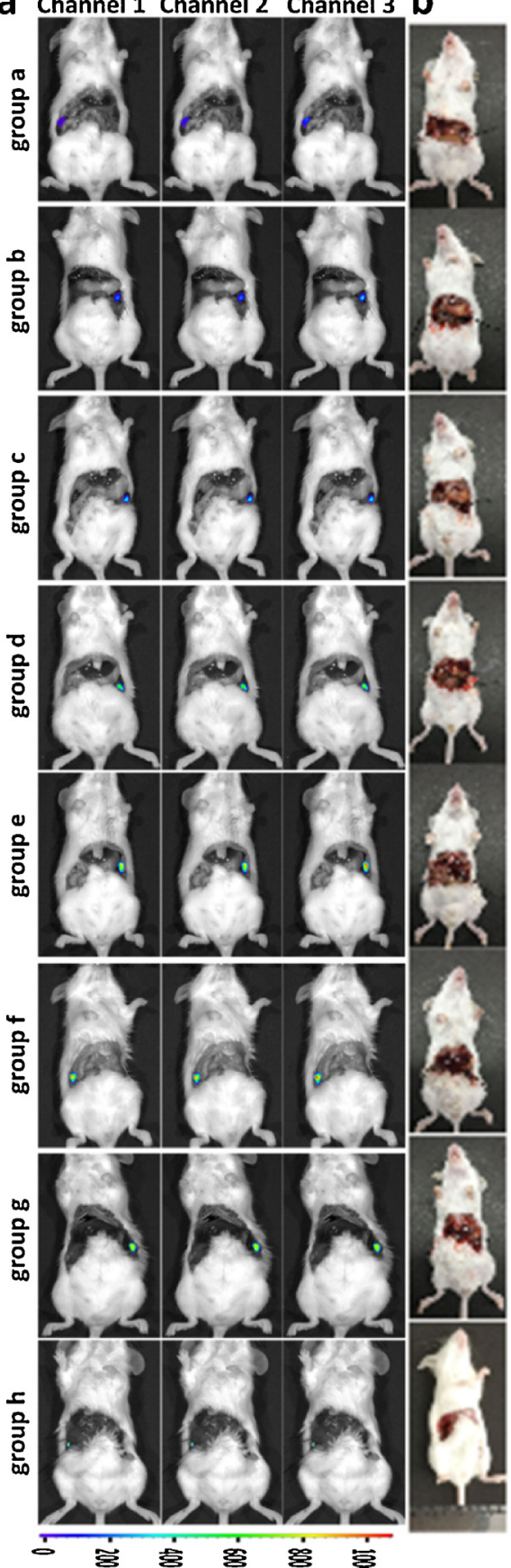
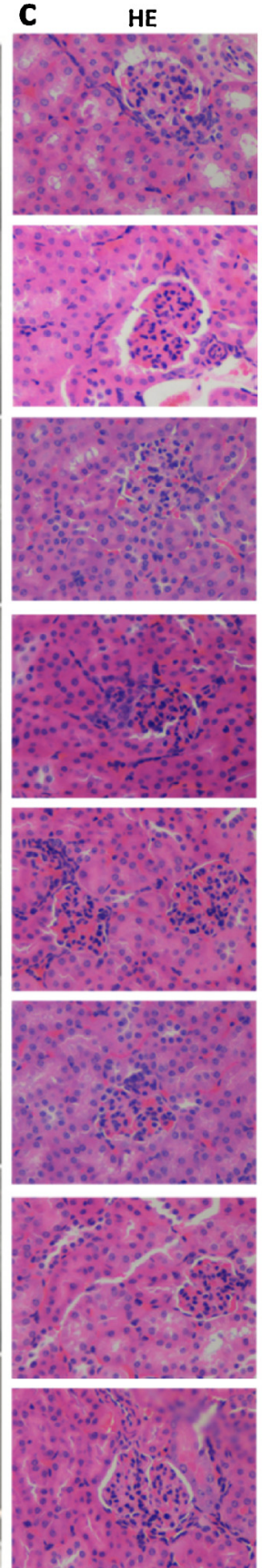
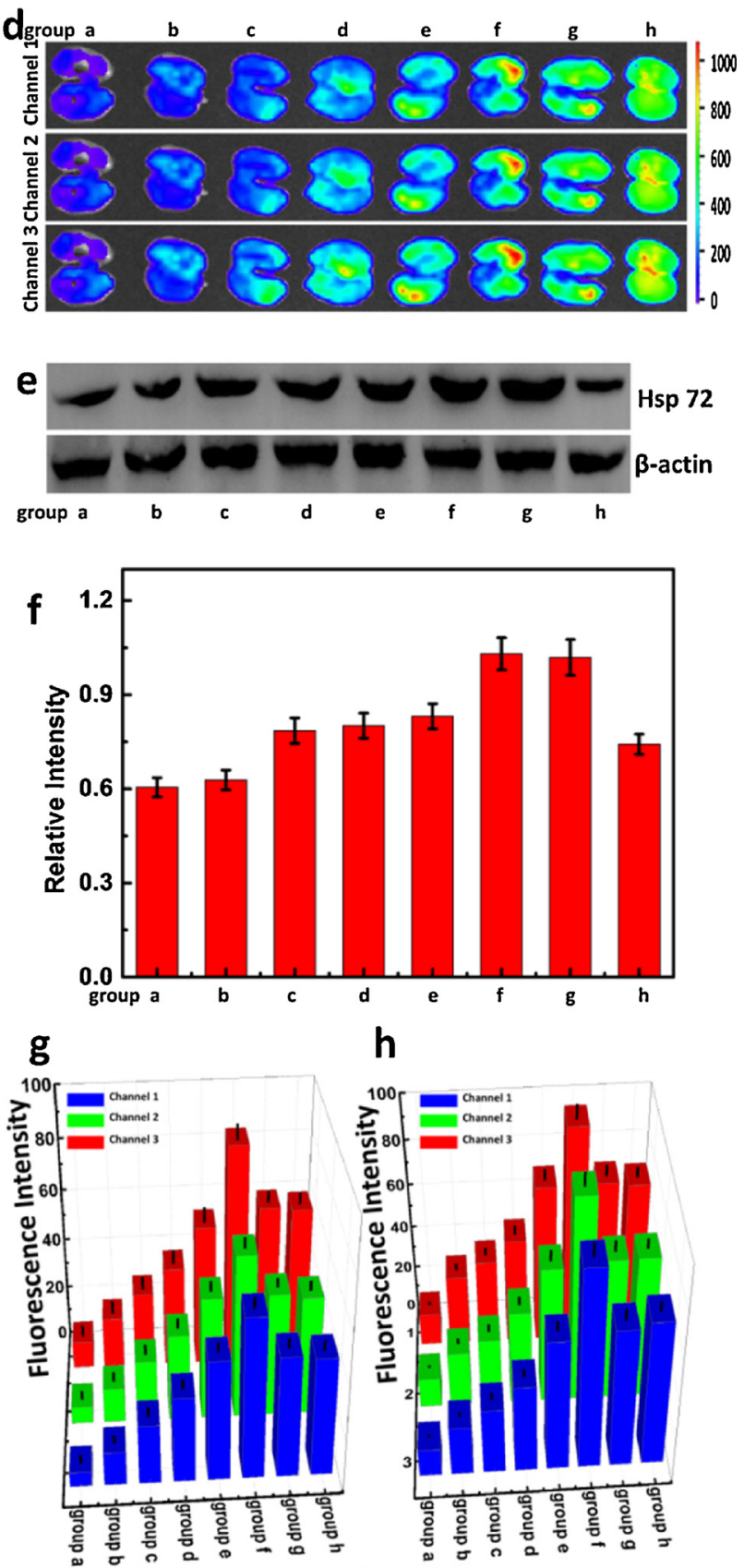

Fig. 4. $\mathrm{O}_{2} \cdot{ }^{--}$and $\mathrm{Hg}^{2+}$ associated-detection in mice model of acute mercury exposure. (a) Orthotopic injection assay. (b) Bright fields of the mice in (a). (c) H\&E staining of the kidney sections (d) Ex vivo fluorescence imaging of separated kidneys from the mice in different groups. (e) Western blot analysis of hsp 72 . (f) The relative intensity analysis of hsp 72. (g) The relative fluorescence quantitative analysis of (a). (h) The relative fluorescence quantitative analysis of (d). group a: $0.2 \mathrm{ml}$ saline; group b: $4 \mathrm{mg} / \mathrm{kg} \mathrm{HgCl} 2,0.2 \mathrm{ml}$; group c: $8 \mathrm{mg} / \mathrm{kg} \mathrm{HgCl} 2,0.2 \mathrm{ml}$; group d: $12 \mathrm{mg} / \mathrm{kg} \mathrm{HgCl}_{2}, 0.2 \mathrm{ml}$; group e: $16 \mathrm{mg} / \mathrm{kg} \mathrm{HgCl}, 0.2 \mathrm{ml}$; group f: $20 \mathrm{mg} / \mathrm{kg} \mathrm{HgCl}$, $0.2 \mathrm{ml}$; group g: $20 \mathrm{mg} / \mathrm{kg} \mathrm{HgCl}_{2}, 0.2 \mathrm{ml} .2 .89 \mu \mathrm{M} / \mathrm{kg}$ sodium selenite; group h: $20 \mathrm{mg} / \mathrm{kg} \mathrm{HgCl}_{2}, 0.2 \mathrm{ml} .2 .89 \mu \mathrm{M} / \mathrm{kg}$ selenocysteine.

experimental requirements, the stability of the probe was firstly detected using spectral detection (Fig. S5). The results indicated that the probe was stable enough to perform long-term experimental tests. Then we established the mice model of chronic mercury exposure for mercury poisoning detection. Furthermore, we wanted to compare the fluctuation of $\mathrm{O}_{2} \cdot$ - and $\mathrm{Hg}^{2+}$ during acute and chronic mercury exposures. The mice in Fig. 5a were divided into eight groups. The mice in group a were given $0.2 \mathrm{ml}$ saline/day as control for 30 days. The mice in group $\mathbf{b}$ were given $0.2 \mathrm{ml}$ of $\mathrm{HgCl}_{2}$ solution $(18 \mathrm{mg} / \mathrm{kg}$ ) orally by gavage for 10 days. The mice in other groups were manipulated as described in group $\mathbf{b}$ with different days (group c: 15 days, group d: 20 days, group e: 25 days, group f: 30 days). The mice in group $\mathbf{g}$ and group $\mathbf{h}$ were performed as described in group $\mathbf{f}$ but treated with sodium selenite $(0.5 \mathrm{mg} / \mathrm{kg}, 2.89 \mu \mathrm{M} / \mathrm{kg})$ and selenocysteine $(0.485 \mathrm{mg} /$ $\mathrm{kg}, 2.89 \mu \mathrm{M} / \mathrm{kg}$ ) for 30 days, respectively. The fresh tissue slices from different organs of mice were obtained for the detection of $\mathrm{O}_{2}{ }^{-}-$and $\mathrm{Hg}^{2+}$ with the probe. Fig. $5 \mathrm{a}$ and $\mathrm{S} 17$ showed the fluorescence imaging for $\mathrm{Hg}^{2+}$ and $\mathrm{O}_{2}{ }^{\circ}$ - (channel 1 and channel 2) detection, respectively. We found that the levels of $\mathrm{O}_{2}{ }^{\circ}$ - fluctuated with different gavage days and different organs (Fig. S17). As shown in Fig. S17, among the 


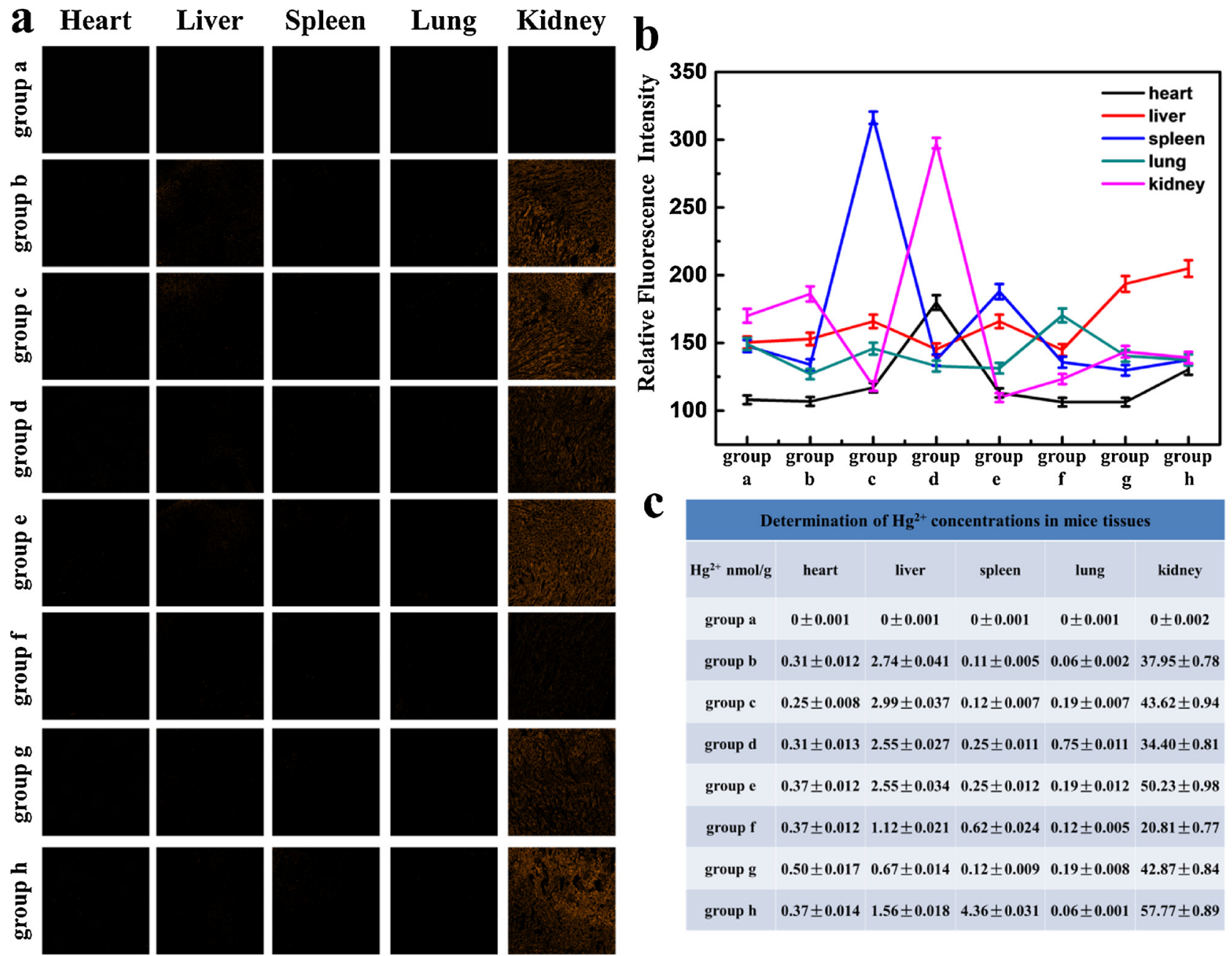

Fig. 5. (a) $\mathrm{Hg}^{2+}$ detection in different organ slices. (b) $\mathrm{O}_{2}{ }^{-{ }^{-}}$detection in different organs with commercial ROS probe. (c) $\mathrm{Hg}^{2+}$ detection in different organs by ICPMS. group a: $0.2 \mathrm{ml}$ saline; group b: $18 \mathrm{mg} / \mathrm{kg} \mathrm{HgCl}{ }_{2}$ for 10 days; group c: $18 \mathrm{mg} / \mathrm{kg} \mathrm{HgCl} 2$ for 15 days; group d: $18 \mathrm{mg} / \mathrm{kg} \mathrm{HgCl}$ for 20 days; group e: $18 \mathrm{mg} / \mathrm{kg} \mathrm{HgCl} 2$ for 25 days; group f: $18 \mathrm{mg} / \mathrm{kg} \mathrm{HgCl}$ for 30 days; group g: $18 \mathrm{mg} / \mathrm{kg} \mathrm{HgCl}_{2}$ for 30 days and $2.89 \mu \mathrm{M} / \mathrm{kg}$ sodium selenite for 30 days; group h: $18 \mathrm{mg} / \mathrm{kg} \mathrm{HgCl}{ }_{2}$ for 30 days and $2.89 \mu \mathrm{M} / \mathrm{kg}$ selenocysteine for 30 days.

different organs, dramatic increases appeared in spleen at 15th day and kidney at 20th day. The level of $\mathrm{O}_{2}{ }^{-}$- in liver kept a continuous enhancement. However, the burst of $\mathrm{O}_{2}{ }^{--}$in heart was not the same as that in acute mercury exposure models. The $\mathrm{O}_{2}{ }^{-}$- burst emerged in heart at 20th day. We also found that even treated with antagonists, the levels of ROS still kept rising, which posed a huge challenge to the treatment of mercury exposure. The concentrations of $\mathrm{O}_{2}{ }^{\circ}$ - were confirmed by the commercial ROS probe 2,7-dichlorodihydrofluorescein diacetate (Fig. 5b), and the results were in good line with the fluorescence imaging. For $\mathrm{Hg}^{2+}$ detection, the fluorescence emissions from kidney were stronger than that from other organs (Fig. 5a). We observed that the accumulation of $\mathrm{Hg}^{2+}$ in kidney reached its maximum concentration at the 25th day even the concentration fluctuated during the process of chronic mercury exposure. After the 25th day, the concentration of $\mathrm{Hg}^{2+}$ in kidney started an obvious decrease. We supposed that the reduction of $\mathrm{Hg}^{2+}$ were attributed to the initialization of organism's selfprotection mechanism. However, the concentrations of $\mathrm{Hg}^{2+}$ in group $\mathbf{g}$ and $\mathbf{h}$ showed relatively high values. We speculated that the seleniumcontaining antagonists would react with $\mathrm{Hg}^{2+}$ to form mercury-selenium complex, which hindered and reduced mercury efflux [30]. Besides, the concentration of $\mathrm{Hg}^{2+}$ was also confirmed by ICP-MS (Fig. 5c), and the results obtained by the different methods were identical. Thus regardless of acute mercury exposure or chronic mercury exposure, $\mathrm{Hg}^{2+}$ mainly gathered in the kidney. The concentration of $\mathrm{Hg}^{2+}$ in acute mercury exposure increased with the increasing $\mathrm{Hg}^{2+}$ dose. However, the concentration of $\mathrm{Hg}^{2+}$ in chronic mercury exposure reached the maximum value at the 25 th day then decreased.

The orthotopic injection assays were performed on mice models of chronic mercury exposure. As shown in Fig. 6a, the concentration of $\mathrm{O}_{2}{ }^{-}$- reached the highest value at 20th day and the concentration of $\mathrm{Hg}^{2+}$ arrived the maximum at 25th day. These results were in good accordance with the results from fluorescence slices (Fig. 5 and S17). The fluorescence quantitative analysis was presented in Fig. 6g. The in vitro fluorescence images of kidney were shown in Fig. 6d, and the relative fluorescence quantitative analysis was shown in Fig. 6h. TUNEL staining and PI staining were performed for the evaluation of the degree of tissue damage (Fig. S23). Compared with the control group, the fluorescence intensities in the model mice were much stronger, and the kidney damage was much severer in the model mice. Subsequently, H\& E staining was used for pathology evaluation of the kidney damages (Fig. 6c). In contrast to the control group, the glomeruli in the model groups showed different degree damage. The hsp 72 from the cortex of the kidney was analyzed by western blot, and the results were shown in Fig. 6e. The expression levels of hsp 72 were analyzed by the software Image $J$ and the results were shown in Fig. $6 f$. The protein express reached the maximum value at the 25th day and we thought that these results were caused by the accumulation of mercury. In the treatment groups, the amount of protein expression decreased slightly but can't 
a
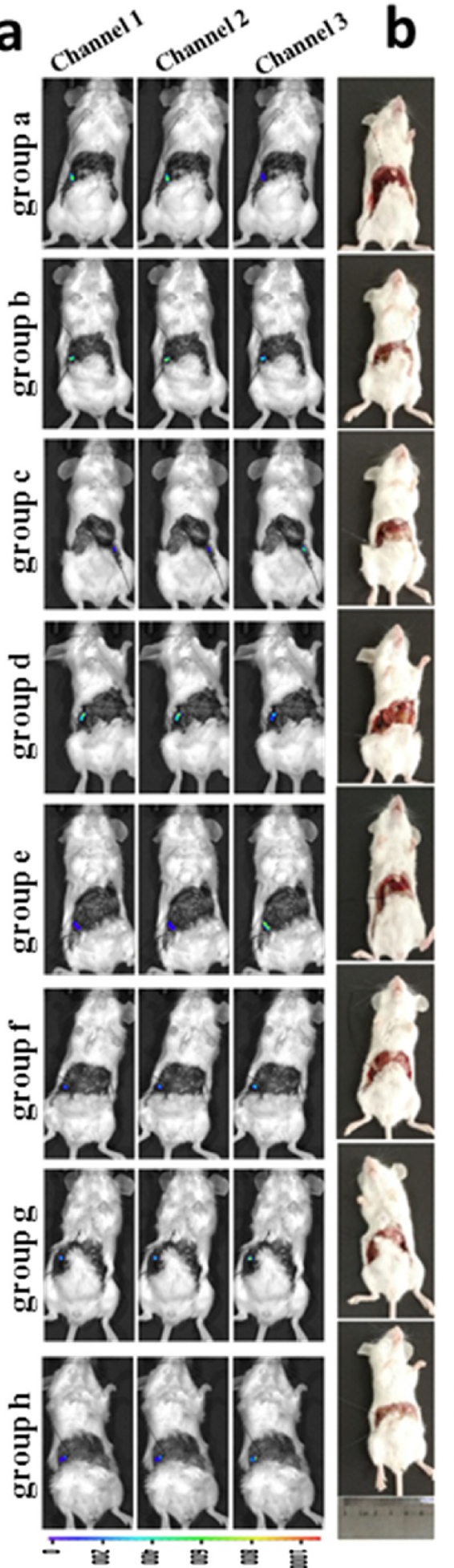
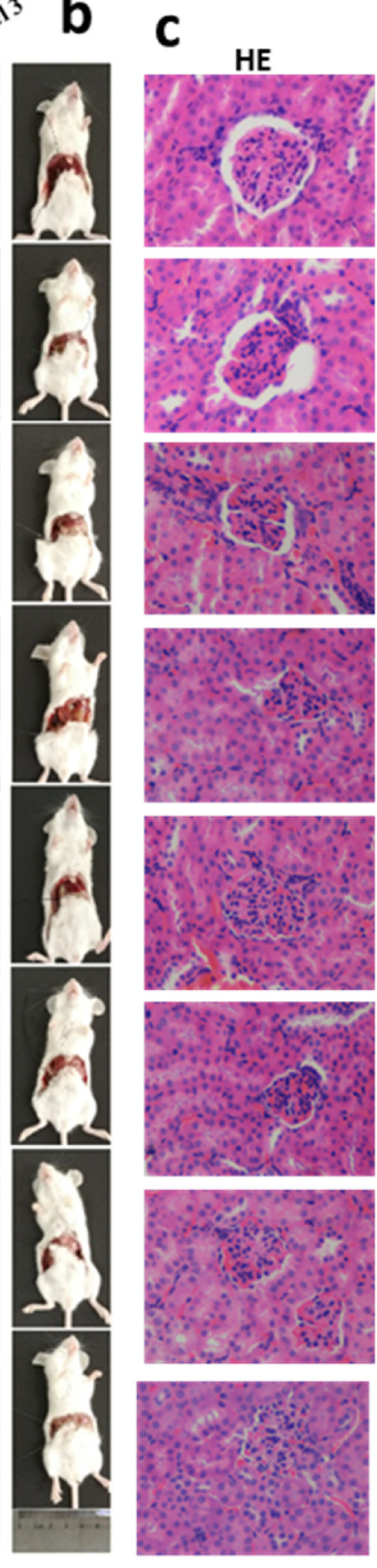

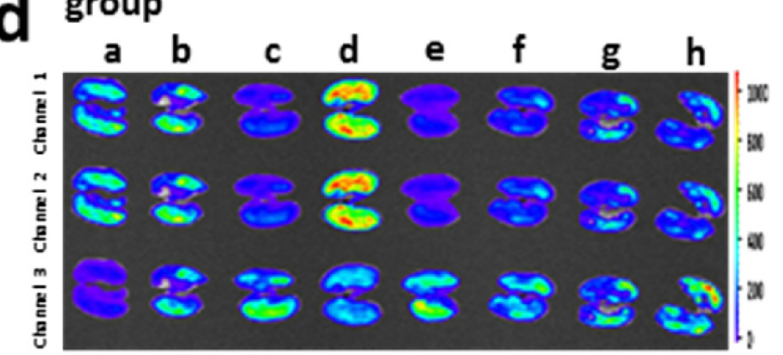

e
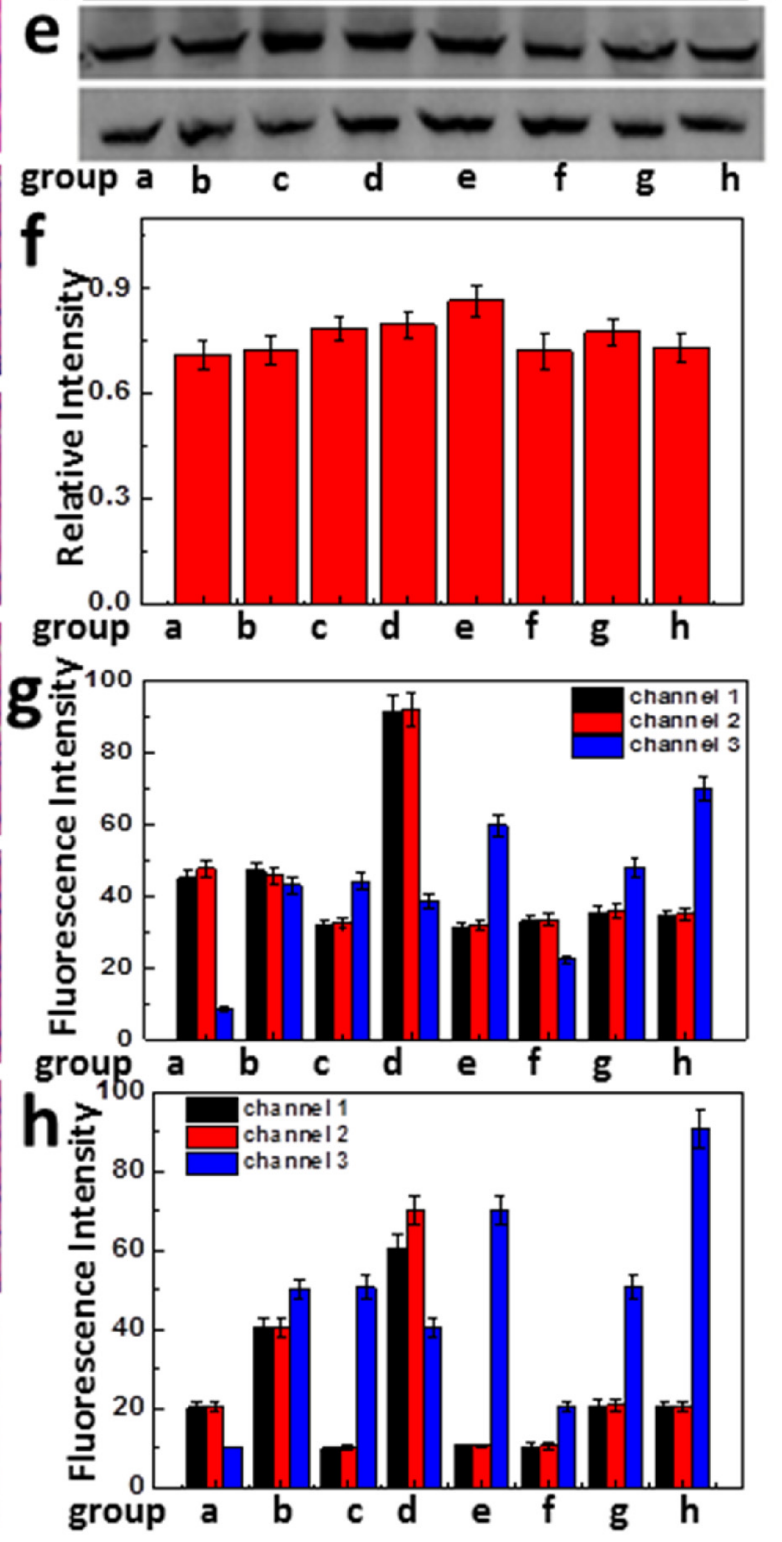

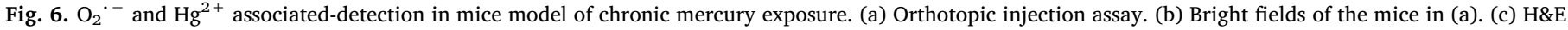

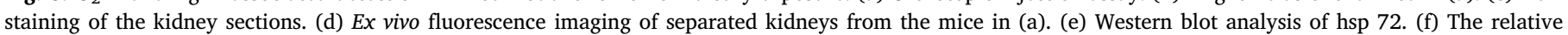

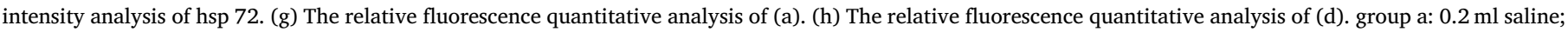

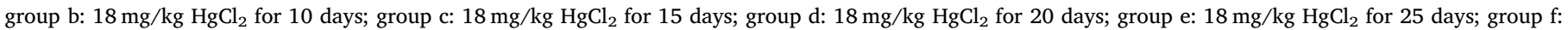

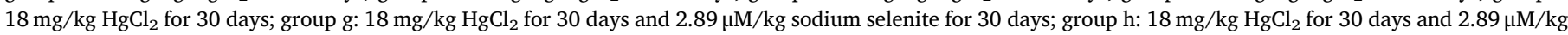
selenocysteine for 30 days.

return to normal levels immediately, and the reason may be due to the fact that the recovery of protein indicators took time. These results demonstrated that both sodium selenite and selenocysteine can protect organisms from mercury poisoning through mercury antagonism.

\section{Conclusion}

In conclusion, we have developed a three-channel ratiometric fluorescent probe $\mathrm{HCy}-\mathrm{SH}$ for assessment of acute/chronic mercury 
exposure via associated determination of $\mathrm{O}_{2}{ }^{--}$and $\mathrm{Hg}^{2+}$. The probe was applied for in situ and real-time imaging of $\mathrm{O}_{2}{ }^{\cdot-}$ and $\mathrm{Hg}^{2+}$ in living cells and mice models of acute/chronic mercury exposure. The experimental results indicated that $\mathrm{Hg}^{2+}$ caused serious damage to organisms. $\mathrm{O}_{2} \cdot$ - burst was much severer in acute mercury exposure than chronic mercury exposure, especially in heart. $\mathrm{Hg}^{2+}$ mainly accumulated in kidney in both acute and chronic mercury exposure. Sodium selenite and selenocysteine can be used as antagonists to protect organisms from mercury poisoning. Furthermore, the oxidative stress caused by mercury exposure must be noticed. Therefore, the probe is a promising chemical analytical tool for mercury poisoning detection in vivo.

\section{Declaration of Competing Interest}

The authors declare no competing financial interest.

\section{Acknowledgments}

We thank the National Nature Science Foundation of China (Nos. 21976209, 21575159, 21775162, 21405172, and 21522706), the program of Youth Innovation Promotion Association, CAS (Grant 2015170), State Key Laboratory of Environmental Chemistry and Ecotoxicology, and Research Center for Eco-Environmental Sciences, CAS (Grant KF2016-22).

\section{Appendix A. Supplementary data}

Supplementary material related to this article can be found, in the online version, at doi:https://doi.org/10.1016/j.snb.2019.127038.

\section{References}

[1] O.J. Paris, J.P. Swaddle, D.A. Cristol, Exposure to dietary methyl-mercury solely during embryonic and juvenile development halves subsequent reproductive success in adult zebra finches, Environ. Sci. Technol. 52 (2018) 3117-3124.

[2] J. Li, K.G. Drouillard, B. Branfireun, G.D. Haffner, Comparison of the toxicokinetics and bioaccumulation potential of mercury and polychlorinated biphenyls in goldfish (Carassius auratus), Environ. Sci. Technol. 499 (2015) 11019-11027.

[3] B.K. Rani, S.A. John, Fluorogenic mercury ion sensor based on pyrene-amino mercapto thiadiazole unit, J. Hazard. Mater. 343 (2018) 98-106.

[4] B. Khan, A. Hameed, A. Minhaz, Synthesis and characterisation of calix [4] arene based bis (triazole)-bis (hexahydroquinoline): probing highly selective fluorescence quenching towards mercury $\left(\mathrm{Hg}^{2+}\right.$ ) analyte, J. Hazard. Mater. 347 (2018) 349-358.

[5] J. Ding, H. Li, C. Wang, J. Yang, Y. Xie, Q. Peng, Q. Li, Z. Li, "Turn-on" fluorescent probe for mercury (II): high selectivity and sensitivity and new design approach by the adjustment of the $\pi$-bridge, ACS Appl. Mater. Interface 7 (2015) 11369-11376.

[6] Y.K. Yang, S.K. Ko, I. Shin, J. Tae, Synthesis of a highly metal-selective rhodaminebased probe and its use for the in vivo monitoring of mercury, Nat. Protoc. 2 (2007) $1740-1745$.

[7] B. Hu, L.L. Hu, M.L. Chen, J.H. Wang, A FRET ratiometric fluorescence sensing system for mercury detection and intracellular colorimetric imaging in live Hela cells, Biosens. Bioelectron. 49 (2013) 499-505.

[8] Y. Wang, M. Gao, Q.G. Chen, F.B. Yu, G.B. Jiang, L.X. Chen, Associated detection of superoxide anion and mercury (II) under chronic mercury exposure in cells and mice models via a three-channel fluorescent probe, Anal. Chem. 90 (2018) 9769-9778.

[9] X. Han, X. Song, F. Yu, L. Chen, A ratiometric near-Infrared fluorescent probe for quantification and evaluation of selenocysteine-protective effects in acute inflammation, Adv. Funct. Mater. 27 (2017).

[10] A.S. Rahmanto, M.J. Davies, Selenium-containing amino acids as direct and indirect antioxidants, IUBMB Life 64 (2012) 863-871.

[11] Y. Huang, F. Yu, J. Wang, L. Chen, Near-infrared fluorescence probe for in situ detection of superoxide anion and hydrogen polysulfides in mitochondrial oxidative stress, Anal. Chem. 88 (2016) 4122-4129.

[12] (a) R.Q. Li, Z.Q. Mao, L. Rong, N. Wu, Q. Lei, J.Y. Zhu, L. Zhuang, X.Z. Zhang, Z.H. Liu, A two-photon fluorescent probe for exogenous and endogenous superoxide anion imaging in vitro and in vivo, Biosens. Bioelectr. 87 (2017) 73-80; (b) X. Gao, G. Feng, P.N. Manghnani, F. Hu, N. Jiang, J. Liu, B. Liu, J.Z. Sun, B.Z. Tang, A two-channel responsive fluorescent probe with AIE characteristics and its application for selective imaging of superoxide anions in living cells, Chem. Commun. 53 (2017) 1653-1656.

[13] (a) A. Stacchiotti, F. Morandini, F. Bettoni, Stress proteins and oxidative damage in a renal derived cell line exposed to inorganic mercury and lead, Toxicology 264

\section{(2009) 215-224}

(b) P.L. Goering, D.L. Morgan, S.F. Ali, Effects of mercury vapor inhalation on reactive oxygen species and antioxidant enzymes in rat brain and kidney are minimal, J. Appl. Toxicol. 22 (2002) 167-172.

[14] F. Si, Y. Liu, K. Yan, W. Zhong, A mitochondrion targeting fluorescent probe for imaging of intracellular superoxide radicals, Chem. Commun. 51 (2015) 7931-7934.

[15] K. Abbas, M. Hardy, F. Poulhes, H. Karoui, P. Tordo, O. Ouari, F. Peyrot, Detection of superoxide production in stimulated and unstimulated living cells using new cyclic nitrone spin traps, Free Rad. Bio Med. 71 (2014) 281-290.

[16] H. Yasui, H. Sakurai, Chemiluminescent detection and imaging of reactive oxygen species in live mouse skin exposed to UVA, Biochem. Biophys. Res. Commun. 269 (2000) 131-136.

[17] J.S. dos Santos, M. de la Guardia, A. Pastor, M.L. Pires dos Santos, Determination of organic and inorganic mercury species in water and sediment samples by HPLC online coupled with ICP-MS, Talanta 80 (2009) 207-211.

[18] Q. Zhu, L. Liu, Y. Xing, Duplex functional G-quadruplex/NMM fluorescent probe for label-free detection of lead (II) and mercury (II) ions, J. Hazard. Mater. 355 (2018) 50-55.

[19] S. Mandal, A. Banerjee, S. Lohar, Selective sensing of $\mathrm{Hg}^{2+}$ using rhodamine-thiophene conjugate: red light emission and visual detection of intracellular $\mathrm{Hg}^{2+}$ at nanomolar level, J. Hazard. Mater. 261 (2013) 198-205.

[20] L. Han, S.G. Liu, J.Y. Liang, pH-mediated reversible fluorescence nanoswitch based on inner filter effect induced fluorescence quenching for selective and visual detection of 4-nitrophenol, J. Hazard. Mater. 362 (2019) 45-52.

[21] Y. Li, Y. Wang, S. Yang, Y. Zhao, L. Yuan, J. Zheng, R. Yang, Hemicyanine-based high resolution ratiometric near-infrared fluorescent probe for monitoring $\mathrm{pH}$ changes in vivo, Anal. Chem. 87 (2015) 2495-2503.

[22] K.Y. Zhang, J. Zhang, Y. Liu, S. Liu, P. Zhang, Q. Zhao, Y. Tang, W. Huang, Coreshell structured phosphorescent nanoparticles for detection of exogenous and endogenous hypochlorite in live cells via ratiometric imaging and photoluminescence lifetime imaging microscopy, Chem. Sci. 6 (2015) 301-307.

[23] K. Gu, Y. Xu, H. Li, Z. Guo, S. Zhu, S. Zhu, P. Shi, T.D. James, H. Tian, W.-H. Zhu, Real-time tracking and in vivo visualization of beta-galactosidase activity in colorectal tumor with a ratiometric near-infrared fluorescent probe, J. Am. Chem. Soc. 138 (2016) 5334-5340.

[24] Q. Zhang, Z. Zhu, Y. Zheng, J. Cheng, N. Zhang, Y.-T. Long, J. Zheng, X. Qian, Y. Yang, A three-channel fluorescent probe that distinguishes peroxynitrite from hypochlorite, J. Am. Chem. Soc. 134 (2012) 18479-18482.

[25] J.J. Hu, N.-K. Wong, S. Ye, X. Chen, M.-Y. Lu, A.Q. Zhao, Y. Guo, A.C.-H. Ma, A.Y, H. Leung, J. Shen, D. Yang, Fluorescent probe HKSOX-1 for imaging and detection of endogenous superoxide in live cells and in vivo, J. Am. Chem. Soc. 137 (2015) 6837-6843.

[26] (a) S. Ando, K. Koide, Development and applications of fluorogenic probes for mercury (II) based on vinyl ether oxymercuration, J. Am. Chem. Soc. 133 (2011) 2556-2566;

(b) J. Wang, L. Long, L. Xia, F. Fang, A NIR fluorescent probe for the rapid detection of $\mathrm{Hg}^{2+}$ in living cells and in vivo mice imaging, Methods Appl. Fluores 5 (2017) 025002;

(c) Y. Yang, X. Gou, J. Blecha, H. Cao, A highly selective pyrene based fluorescent sensor toward $\mathrm{Hg}^{2+}$ detection, Tetrahedron Lett. 51 (2010) 3422-3425;

(d) P. Singla, P. Kaur, K. Singh, A fluorescent probe for the detection of $\mathrm{Hg}^{2+}$ : shift from "on-state A" to "on-state B", Talanta 130 (2014) 571-576.

[27] W. Ma, L. Jing, A. Valladares, S.L. Mehta, Z. Wang, P.A. Li, J.J. Bang, Silver nanoparticle exposure induced mitochondrial stress, caspase- 3 activation and cell death: amelioration by sodium selenite, Int. J. Biol. Sci. 11 (2015) 860-867.

[28] E. Pelletier, Mercury-selenium interactions in aquatic organisms: a review, Mar. Environ.Res. 18 (1986) 111-132.

[29] P.L. Goering, B.R. Fisher, B.T. Noren, A. Papaconstantinou, J.L. Rojko, R.J. Marler, Mercury induces regional and cell-specific stress protein expression in rat kidney, Toxicol. Sci. 53 (2000) 447-457.

[30] M.A.K. Khan, F. Wang, Mercury-selenium compounds and their toxicological significance: toward a molecular understanding of the mercury-selenium antagonism, Environ. Toxicol. Chem. 28 (2009) 1567-1577.

[31] J. Xu, B. Han, Synthesis of protein-directed orange/red-Emitting copper nanoclusters via hydroxylamine hydrochloride reduction approach and their applications on $\mathrm{Hg}^{2+}$ sensing, Nano 11 (2016) 1650108.

[32] J. Ding, H. Li, C. Wang, "Turn-on" fluorescent probe for mercury (II): high selectivity and sensitivity and new design approach by the adjustment of the $\pi$-bridge, ACS Appl. Mater. Interface 7 (2015) 11369-11376.

[33] C. Song, W. Yang, N. Zhou, Fluorescent theranostic agents for $\mathrm{Hg}^{2+}$ detection and detoxification treatment, Chem. Commun. 51 (2015) 4443-4446.

[34] X. Zhang, Y. Xiao, X. Qian, A ratiometric fluorescent probe based on FRET for imaging $\mathrm{Hg}^{2+}$ ions in living cells, Angew. Chem. Int. Ed. 47 (2008) 8025-8029.

[35] B. Hu, L.L. Hu, M.L. Chen, A FRET ratiometric fluorescence sensing system for mercury detection and intracellular colorimetric imaging in live Hela cells, Biosens Bioelectron. 49 (2013) 499-505.

[36] Y.J. Gong, X.B. Zhang, C.C. Zhang, Through bond energy transfer: a convenient and universal strategy toward efficient ratiometric fluorescent probe for bioimaging applications, Anal. Chem. 84 (2012) 10777-10784.

[37] X. Han, F. Yu, X. Song, Quantification of cysteine hydropersulfide with a ratiometric near-infrared fluorescent probe based on selenium-sulfur exchange reaction, Chem. Sci. 7 (2016) 5098-5107.

[38] Z. Zang, X. Zeng, M. Wang, Tunable photoluminescence of water-soluble AgInZnS-graphene oxide (GO) nanocomposites and their application in-vivo bioimaging, Sens. Actuator B-Chem. 252 (2017) 1179-1186. 
Yue Wang is currently a doctoral candidate, under the guidance of Prof. Lingxin Chen, at Yantai Institute of Coastal Zone Research, Chinese Academy of Sciences, and has been since 2015. She received her BS from Qufu Normal University, in 2015. Her current research interests focus on the development of functional fluorescent probes for bioimaging.

Min Gao received her PhD degree from Yantai Institute of Coastal Zone Research, Chinese Academy of Sciences, in 2018 under the guidance of Prof. Lingxin Chen. She is now doing post-doctoral research in Prof. Young-Tae Chang's group at the Center for Self-assembly and Complexity, Institute for Basic Science (Korea). Her current work focuses on the development of fluorescent probes for biological imaging.

Chunyang Liao has been a professor at Research Center for Eco-Environmental Science, Chinese Academy of Sciences, since 2015. He obtained his Ph.D. at Research Center for Chinese Academy of Sciences, since 2015. He obtained his Ph.D. at Research Center for
Eco-Environmental Science, Chinese Academy of Sciences, in 2007. He did post-doctoral research group at Wadsworth Research Center, New York State Department of Health during 2009-2013. He served for University of California, Riverside during 2014 - 2015. His research interests include biological enrichment of pollutants and metabolic transformation in vivo, toxicity effects of pollutants especially neurotoxicity, assessment of environmental health risks of pollutants to organisms and humans.

Fabiao Yu is currently a professor at Institute of Functional Materials and Molecular Imaging, Hainan Medical University. He served for Yantai Institute of Coastal Zone Research, Chinese Academy of Sciences during 2013 - 2017. He received his PhD, joint educated, at Dalian University of Technology, and Dalian Institute of Chemical Physics, Chinese Academy of Sciences, in 2013. His research interests focus on functional probe molecules (fluorescence and phosphorescence analysis), theranostics, and organic functional materials.

Lingxin Chen has been a professor at Yantai Institute of Coastal Zone Research, Chinese Academy of Sciences, since 2009. He obtained his Ph.D. in analytical chemistry at Dalian Institute of Chemical Physics, Chinese Academy of Sciences, in 2003. During 2004-2009, he worked at Department of Chemistry, Tsinghua University, and Department of Applied Chemistry, Hanyang University, respectively. His research interests include the studies of novel properties of materials such as functionalized nanoparticles \& functional probe molecules for developing nanoscale biochemical analysis methods and molecular imprinting-based sample pretreatment technology. 